\title{
Net Anthropogenic Phosphorus Accumulation in the Beijing Metropolitan Region
}

\author{
Yuguo Han, Xuyong Li, ${ }^{*}$ and Zhe Nan
}

State Key Laboratory of Urban and Regional Ecology, Research Center for Eco-Environmental Sciences, Chinese Academy of Sciences, Beijing 100085, China

\begin{abstract}
Phosphorus (P) is one of main pollution elements of eutrophication. $\mathrm{P}$ emissions from different pathways and sources are a key issue in the protection of water quality and sustainable watershed management practices. We have estimated net anthropogenic $\mathrm{P}$ accumulation (NAPA), as an index of $\mathrm{P}$ pollution potential in the Beijing metropolitan region, China. The NAPA estimation is based on an inventory of $\mathrm{P}$ fertilizer use, consumption of human food and animal feed, non-food P, and riverine P net flux. The overall average NAPA for 1991, 1997, 2003, and 2007 are 777, 943, 1218, and $1084 \mathrm{~kg} \mathrm{P} \mathrm{km}^{-2} \mathrm{y}^{-1}$, about two times that reported in developed countries. The Urban unit has the largest NAPA (5526 kg P km $\mathrm{k}^{-1}$ ), whereas Mentougou $\mathrm{P}$ was negative, outputting $34 \mathrm{~kg} \mathrm{P}$ $\mathrm{km}^{-2} \mathrm{y}^{-1}$. P input of fertilizer is the largest source
\end{abstract}

\section{INTRODUCTION}

In the 1980s ecologists began to focus on human settlements or urban ecosystems (McDonnell and Pickett 1990). Despite the increased interest in urban systems, there are relatively few data on the basic functional properties of these ecosystems. The heterogeneity of urban ecosystems, with a mix of

Received 30 April 2010; accepted 22 January 2011; published online 15 February 2011

Author Contributions: YH and XL contributed to the design of the study, performed the research, analyzed data, and wrote the article. ZN helped to collect and process the data.

*Corresponding author; e-mail: xyli@rcees.ac.cn of NAPA, accounting for $40.7 \%\left(455 \mathrm{~kg} \mathrm{P} \mathrm{km}^{-2} \mathrm{y}^{-1}\right)$ of the total P input, followed by non-food $\mathrm{P}$ and $\mathrm{P}$ in human food and animal feed. NAPA is closely related to land use, on average $5433 \mathrm{~kg} \mathrm{P} \mathrm{km}^{-2} \mathrm{y}^{-1}$ in densely populated developed land, $503 \mathrm{~kg} \mathrm{P} \mathrm{km}^{-2}$ $\mathrm{y}^{-1}$ in agricultural land and $84 \mathrm{~kg} \mathrm{P} \mathrm{km}^{-2} \mathrm{y}^{-1}$ in forest land. Human population density is the best single predictor of NAPA. Our results provide a basis for understanding the potential impact of anthropogenic $\mathrm{P}$ inputs on environmental problems, such as nation-wide water quality degradation under the current rapid urban expansion in modern China.

Key words: anthropogenic; phosphorus accumulation; phosphorus fertilizer use; food production; non-food $\mathrm{P}$; riverine $\mathrm{P}$. roads, buildings, grass, water infrastructure, agriculture, and natural and semi-natural ecosystems, has made it difficult to evaluate basic ecosystem functions relevant to production, consumption, decomposition, and nutrient flux (Sukopp 1990; Pickett and others 1997, 2001). The interaction of physical, ecological, and social drivers of urban ecosystem structure and function has been a particularly challenging analysis in these ecosystems (Grove and Burch 1997).

Phosphorus $(\mathrm{P})$ is one of main pollution elements of eutrophication. $\mathrm{P}$ emissions from different pathways and sources are a key issue in protection of water quality and sustainable watershed man- 
agement practices (Lowrance and others 1985; McIsaac and others 2001; Denman 2007). There have been a few studies on this issue. For example, Russell and others (2008) conducted a relevant investigation on net anthropogenic phosphorus input (NAPI), and pointed out that NAPI is an important index for predicting $\mathrm{P}$ pollution in a region. They quantified inputs of $\mathrm{P}$ in each unit, most of which are derived from human activities: fertilizer use, human food and animal feed and nonfood P. Nevertheless, none of the studies considered riverine $\mathrm{P}$ import/export in the calculation of anthropogenic phosphorus. However, the natural condition of rivers is increasingly influenced by expanding human activity. Therefore, we introduced a new concept of net anthropogenic phosphorus accumulation (NAPA) and took riverine $\mathrm{P}$ import/export into consideration, that is, NAPA $=\mathrm{P}$ fertilizer use $+\mathrm{P}$ in human food and animal feed + Riverine $\mathrm{P}+$ non-food $\mathrm{P}$.

At present, around the world there are 20 "super cities" where the population is over 10 million (Sun and others 2005). Thus, it is of great significance to evaluate $\mathrm{P}$ accumulation in densely populated cities such as Beijing. The purpose of this paper is to calculate NAPA in the Beijing metropolitan region, and includes three objectives: (a) to quantify the variation in net $\mathrm{P}$ accumulation; (b) to evaluate inputs, outputs, and accumulation of $\mathrm{P}$; and (c) to analyze the main components and forecast which factors will determine NAPA within this metropolitan region in the future. To some extent, this paper overcomes the difficulties in quantifying $\mathrm{P}$ sources arising from complex factors and introduces a new way of studying P accumulation.

\section{MethodS}

\section{Study Sites}

Beijing is located near the western coastline of the Pacific Ocean, at the northern tip of the North China Plain and geomorphologically it is high to the northwest and low to the southeast. The center of Beijing is situated at $39^{\circ} 56^{\prime}$ North Latitude and $116^{\circ} 20^{\prime}$ East Longitude. The Beijing metropolitan region has an area of $16,808 \mathrm{~km}^{2}$, and a population of 17 million, with about half living on the outskirts. The city is 39\% flat land and $61 \%$ mountainous areas. There are eight districts in the urban area and eight districts and two counties in the suburban area. The whole urban area is similar in size to that of the districts or counties in the suburban area, so the eight districts in the urban area have been integrated here into one research unit (Urban unit). Therefore, there are 11 research units in total as shown in Figure 1 and Table 1, including one urban area, eight districts, and two counties. NAPA in the Urban unit was estimated using district-level data (eight districts), and NAPA in each district, or each county of the suburban area was estimated using township-level data (156 townships; in China a township is a basic level of political division between county and village that

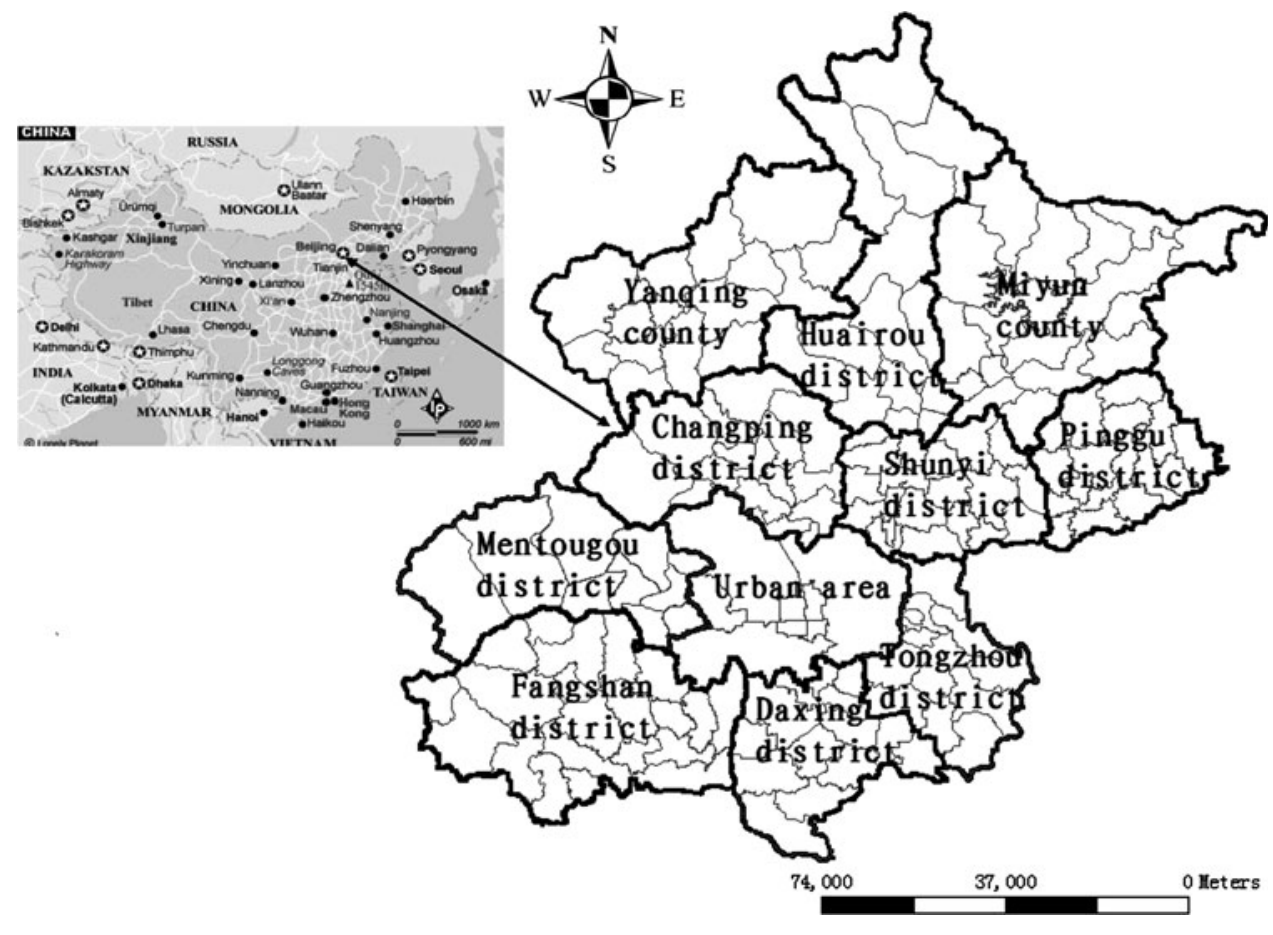

Figure 1. Geographic location of Beijing. This figure presents the distribution of the research units in Beijing. The 11 research units are divided by dark black outlines, and the 164 subunits are divided by light black outlines. 
Table 1. Characteristics of Beijing

\begin{tabular}{|c|c|c|c|c|c|c|c|}
\hline & \multirow{2}{*}{$\begin{array}{l}\text { Area } \\
\left(\mathrm{km}^{2}\right)\end{array}$} & \multirow{2}{*}{$\begin{array}{l}\text { People (ten } \\
\text { thousands) }\end{array}$} & \multicolumn{5}{|l|}{ Land use (\%) } \\
\hline & & & $\begin{array}{l}\text { Agricultural } \\
\text { land }\end{array}$ & $\begin{array}{l}\text { Forest } \\
\text { land }\end{array}$ & $\begin{array}{l}\text { Grass } \\
\text { land }\end{array}$ & $\begin{array}{l}\text { Developed } \\
\text { land }\end{array}$ & $\begin{array}{l}\text { Other } \\
\text { land }\end{array}$ \\
\hline Urban & 1368.3 & 1012.3 & 19.173 & 13.736 & 2.031 & 59.502 & 5.557 \\
\hline Yanqing & 1993.8 & 28.6 & 20.049 & 62.990 & 7.120 & 6.434 & 3.407 \\
\hline Huairou & 2122.6 & 31.6 & 12.480 & 60.819 & 18.470 & 5.456 & 2.785 \\
\hline Miyun & 2229.5 & 44.9 & 19.089 & 49.299 & 14.900 & 6.641 & 10.071 \\
\hline Changping & 1343.5 & 89.6 & 19.406 & 47.830 & 3.689 & 24.745 & 4.330 \\
\hline Shunyi & 1019.9 & 73.6 & 48.667 & 8.308 & 6.209 & 27.936 & 8.880 \\
\hline Pinggu & 950.1 & 42.4 & 37.418 & 34.559 & 11.140 & 12.103 & 4.780 \\
\hline Mentougou & 1450.7 & 27.0 & 3.939 & 70.050 & 18.210 & 6.281 & 1.520 \\
\hline Tongzhou & 906.3 & 96.5 & 53.387 & 5.667 & 1.039 & 28.287 & 11.620 \\
\hline Fangshan & 1989.5 & 88.7 & 20.694 & 36.618 & 21.865 & 16.703 & 4.120 \\
\hline Daxing & 1036.3 & 97.8 & 57.155 & 5.393 & 3.229 & 27.353 & 6.870 \\
\hline
\end{tabular}

This table presents the research units of Beijing. The unit of the area is $\mathrm{km}^{2}$; population data in these units were collected in 2008 with the unit in ten thousands; and the land use is classified as agricultural land, forest land, grass land, developed land and other land, the data of which are presented as percentage and were collected in 2007.

administers several villages). There are a total of 164 subunits in the experiment.

We obtained the data from the Beijing Municipal Bureau of Statistics and the Beijing Municipal Commission of Population and Family Planning. Land cover was derived from satellite images of the Beijing Municipal Bureau of Land and Resources and from previous studies (Yan and Ma 2007). We calculated $\mathrm{P}$ accumulation values for the years 1991, 1997, 2003, and 2007.

\section{NAPA Estimation Approach}

NAPA was estimated by accounting for the anthropogenic $\mathrm{P}$ input/output in each unit. We quantified inputs of $\mathrm{P}$ in each unit, most of which were derived from the human activities: fertilizer use, human food and animal feed and non-food P (Russell and others 2008). As we mentioned above, most previous studies excluded riverine $\mathrm{P}$ net flux from the human activity category. However, the five major river systems in Beijing are inland rivers and are influenced significantly by human activities, such as Jiyun River, which is an artificial river and is mainly used for sewage disposal (Sun and

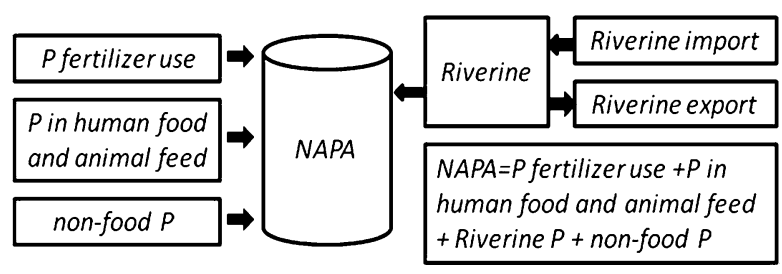

Figure 2. Flow of NAPA. It shows the composition and sources of NAPA as well as how NAPA was calculated. The arrows in the figure guide the flow way of NAPA. others 2005). Rivers affect NAPA in Beijing directly, or indirectly, so we also took into account their P import/export (Figure 2).

\section{P Fertilizer Use}

Current management practices in agricultural production are largely based on intensive fertilizer use, so it is one of the important $\mathrm{P}$ sources of NAPA. We obtained data on the amount of applied $\mathrm{P}$ fertilizer within each subunit from the Beijing Municipal Bureau of Statistics and Rural Affairs Committee. Estimates of fertilizer application are available for each subunit. $\mathrm{P}$ fertilizer contains $12-18 \%$ of $\mathrm{P}_{2} \mathrm{O}_{5}$ (Liang 1999; Gao and others 2001). Total $\mathrm{P}$ fertilizer applications were converted to $\mathrm{kg} \mathrm{P}$ by multiplying by $436.4 \mathrm{~kg} \mathrm{P}$ per ton $\mathrm{P}_{2} \mathrm{O}_{5}$.

\section{Net P Input/Output in Human Food and Animal Feed}

Humans and animals require a great deal of food and feed during their lives, so net $\mathrm{P}$ in human food and animal feed is also an important component of NAPA. Human food and animal feed are related to input/output $\mathrm{P}$ of agricultural products. With a few exceptions, we used the general method introduced by Jordan and Weller (1996), who quantified the net input of $\mathrm{P}$ as:

net input/output in food and feed $=$ food and feed consumption of humans and animals - animal production for human consumption - crop production. 
We obtained crop and animal production data from the China Beijing Municipal Bureau of Statistics, and human population counts from the Beijing Municipal Commission of Population and Family Planning. Each item, as well as the final result, in this method is presented with subunitlevel data.

\section{Food and Feed Consumption}

Human consumption of $\mathrm{P}$ in food was estimated by multiplying the number of inhabitants in each subunit (see Table 2) by a per capita intake of $0.52 \mathrm{~kg}$ P per year (Wu 2005). The P consumption per individual was then multiplied by the number of each animal type in each subunit. We chose the values of consumption reported by $\mathrm{Wu}$ (2005) and the values for the percentage $\mathrm{P}$ excreted reported by Van Horn (1998). We assumed all animals are completely formula fed, with $80 \%$ from corn and $20 \%$ from pasture (Li 2007).

\section{Crop Production}

We chose one vegetable and 14 main agricultural crops to estimate the P production in each subunit. The vegetable crop was represented by cabbage because phosphorus content was slightly different between different kinds of vegetables. We calculated the $\mathrm{P}$ content of the crop harvest in each subunit. The P content $\left(\mathrm{g} \mathrm{kg}^{-1}\right)$ for each crop type has been reported by Wang (2003) as shown in Table 3. We assumed that pests, spoilage, and processing caused a $10 \%$ loss for all crops (Jordan and Weller 1996).

\section{Animal Production}

The animal P production category includes meat, milk, eggs, and so. We estimated animal $\mathrm{P}$ production as the difference between animal feed consumption (intake) and animal excretion (waste production). We assumed that spoilage and inedible components caused a $10 \%$ loss of animal products available for consumption.

\section{Non-Food P}

Non-food P mainly comes from the detergent in people's daily life. In China, the pollution emission is $150 \mathrm{l}$ per person per day. As measured by Shang (2009), the concentration of total $\mathrm{P}$ in Beijing household sewage was $21 \mathrm{mg} \mathrm{l}^{-1}$. There are 365 days in 1 year, so the $\mathrm{P}$ discharged from household sewage was $1.15 \mathrm{~kg}$ per person per year. As $\mathrm{P}$ discharged from human excretion was $0.52 \mathrm{~kg}$ per person per year, the remaining $\mathrm{P}$, that is, nonfood was $0.63 \mathrm{~kg}$ per person per year. In other words, household sewage discharge was estimated to be only $45 \%$ derived from human excretion of $\mathrm{P}$, with the other $55 \%$ coming from non-food phosphorus uses such as laundry, bathing, and food wastes from garbage disposals.

\section{Riverine Net Flux}

There are five water systems in Beijing, that is, Daqing River, Yongding River, Beiyun River, Jiyun River, and Chaobai River. The accumulation of $\mathrm{P}$ in these rivers was quantified as:

$$
\begin{aligned}
& \text { riverine } \mathrm{P} \text { net flux }=\text { import } \mathrm{P} \text { concentration } \\
& \times \text { import quantity of water }- \text { export } \mathrm{P} \\
& \text { concentration } \times \text { export quantity of water }
\end{aligned}
$$

Due to limited data on water quality monitoring in Beijing, values for only 3 years, 2006-2008, were available. We obtained data on water quantity and quality from the Beijing Water Authority and Beijing Hydrologic Center (Table 4). The variation in riverine $\mathrm{P}$ net flux across these years is

Table 2. Animal and Human P Consumption and Excretion

\begin{tabular}{lllcc}
\hline Animal type & $\begin{array}{l}\text { Waste production } \\
\text { (P excretion, kg P }^{\text {individual }} \begin{array}{l}-1 \\
\mathrm{y}^{-1} \text { ) }\end{array}\end{array}$ & $\begin{array}{l}\text { Percent } \\
\text { excreted }\end{array}$ & $\begin{array}{l}\text { Consumption } \\
\text { (P intake rates, kg P }_{\text {individual }^{-1} \mathbf{y}^{-1} \text { ) }}\end{array}$ & $\begin{array}{l}\text { Animal } \\
\text { production (kg P } \\
\text { individual }^{-1} \mathbf{Y}^{-1} \text { ) }\end{array}$ \\
\hline Hogs and pigs & 3.17 & 0.69 & 4.59 & 1.42 \\
Horses and cattle & 9.78 & 0.89 & 10.99 & 1.21 \\
Chickens & 0.12 & 0.65 & 0.18 & 0.06 \\
Duck & 0.22 & 0.65 & 0.34 & 0.12 \\
Sheep and lambs & 1.06 & 0.84 & 1.26 & 0.20 \\
Human & 0.52 & 1 & 0.52 & 0
\end{tabular}


Table 3. P Content of Agricultural Crop Production

\begin{tabular}{ll}
\hline Crop type & P $\left(\mathrm{g} \mathrm{kg}^{-1}\right)$ \\
\hline Corn & 2.44 \\
Wheat & 1.88 \\
Soybeans & 4.65 \\
Paddy & 1.1 \\
Millet & 2.99 \\
Broomcorn & 3.29 \\
Peanuts & 2.5 \\
Vegetables & 0.3 \\
Potatoes & 0.4 \\
Chestnut & 0.89 \\
Apples & 0.12 \\
Grapes & 0.13 \\
Peaches & 0.14 \\
Pears & 0.13 \\
Watermelon & 0.12 \\
& \\
\hline Data from Wang (2003). & \\
\hline
\end{tabular}

quite slight, so we used average values for the riverine $\mathrm{P}$ calculations.

\section{Data Analyses}

\section{Analysis and Calculation of NAPA}

Based on P fertilizer use, $\mathrm{P}$ in human food and animal feed, non-food P and riverine P, NAPA was calculated by summing the values for all research units within Beijing. Geographic and spatial analysis of NAPA was conducted using average NAPA values in the 164 subunits for the years 1991, 1997, 2003, and 2007. The land-cover data were used with the ArcInfo 9.2 (ESRI Inc.) geographic information system to calculate the proportions of row crops and forest in each unit, whereas the average number of animal units was calculated from agricultural census the data for years 1991, 1997, 2003, and 2007. We also examined differences in NAPA and its components among countries.

\section{Proxy Variables for NAPA}

To evaluate the feasibility of using fertilizer application and human population density as proxies for the more intensive NAPA calculations, we used step-wise linear regression to fit empirical models to predict NAPA from the potential proxy variables with SPSS Statistics 17.02 (WinWrap Basic). Variables were log transformed to address issues of nonnormality in the data.

\section{RESUlts}

\section{Spatial Variation of NAPA}

Figure 3 shows the geographic differences of NAPA in Beijing. Over the past 16 years, $\mathrm{P}$ accumulation in the Urban unit, especially in its four central districts, was much more significant than in other areas. The Urban unit has the largest NAPA (5526 kg P km $\mathrm{kg}^{-2} \mathrm{y}^{-1}$ ), whereas Mentougou $\mathrm{P}$ is negative, outputting $34 \mathrm{~kg} \mathrm{P} \mathrm{km}^{-2} \mathrm{y}^{-1}$; the difference between these two units is as large as $5560 \mathrm{~kg}$ $\mathrm{P} \mathrm{km}^{-2} \mathrm{y}^{-1}$. The average NAPA values in the Urban and suburban areas for the years of 1991, 1997, 2003, and 2007 are 777, 943, 1218, and $1084 \mathrm{~kg} \mathrm{P}$ $\mathrm{km}^{-2} \mathrm{y}^{-1}$, respectively (Table 5).

Table 4. Riverine P Import and Export

\begin{tabular}{|c|c|c|c|c|c|c|}
\hline P flux $\left(10^{5} \mathrm{~kg}\right)$ & $\begin{array}{l}\text { Daqing } \\
\text { River }\end{array}$ & $\begin{array}{l}\text { Yongding } \\
\text { River }\end{array}$ & $\begin{array}{l}\text { Beiyun } \\
\text { River }\end{array}$ & $\begin{array}{l}\text { Jiyun } \\
\text { River }\end{array}$ & $\begin{array}{l}\text { Chaobai } \\
\text { River }\end{array}$ & $\begin{array}{l}\text { P total } \\
\left(\mathrm{kg} \mathrm{P} \mathrm{y}^{-1}\right)\end{array}$ \\
\hline \multicolumn{7}{|l|}{2006} \\
\hline P import & 0.164 & 0.575 & & 0.003 & 0.078 & \\
\hline $\mathrm{P}$ export & 0.002 & & 20.069 & 0.391 & & \\
\hline P net flux & +0.162 & +0.575 & -20.069 & -0.388 & +0.078 & -19.642 \\
\hline \multicolumn{7}{|l|}{2007} \\
\hline P import & 0.014 & 0.588 & & 0.001 & 0.072 & \\
\hline $\mathrm{P}$ export & 0.010 & 0 & 15.533 & 0.323 & 0 & \\
\hline P net flux & +0.004 & +0.588 & -15.533 & -0.322 & +0.072 & -15.191 \\
\hline \multicolumn{7}{|l|}{2008} \\
\hline P import & 0.313 & 0.506 & & 0.012 & 0.074 & \\
\hline $\mathrm{P}$ export & 0.042 & 0 & 19.328 & 0.285 & 0 & \\
\hline P net flux & +0.271 & +0.506 & -19.328 & -0.273 & +0.074 & -18.751 \\
\hline Area $\left(\mathrm{km}^{2}\right)$ & 2,219 & 3,168 & 4,423 & 1,377 & 5,613 & 16,800 \\
\hline Average-weighted $\left(\mathrm{kg} \mathrm{P} \mathrm{km}^{-2} \mathrm{y}^{-1}\right)$ & +6.56 & +17.56 & -413.97 & -23.79 & +1.33 & -106.32 \\
\hline
\end{tabular}

The boundaries of the river basins do not overlap those of the subunits, so we accounted $P$ accumulation per unit area in each river basin, and obtained $P$ accumulation in each subunit according to its actual area. "+" means P input; "-" means P output. 


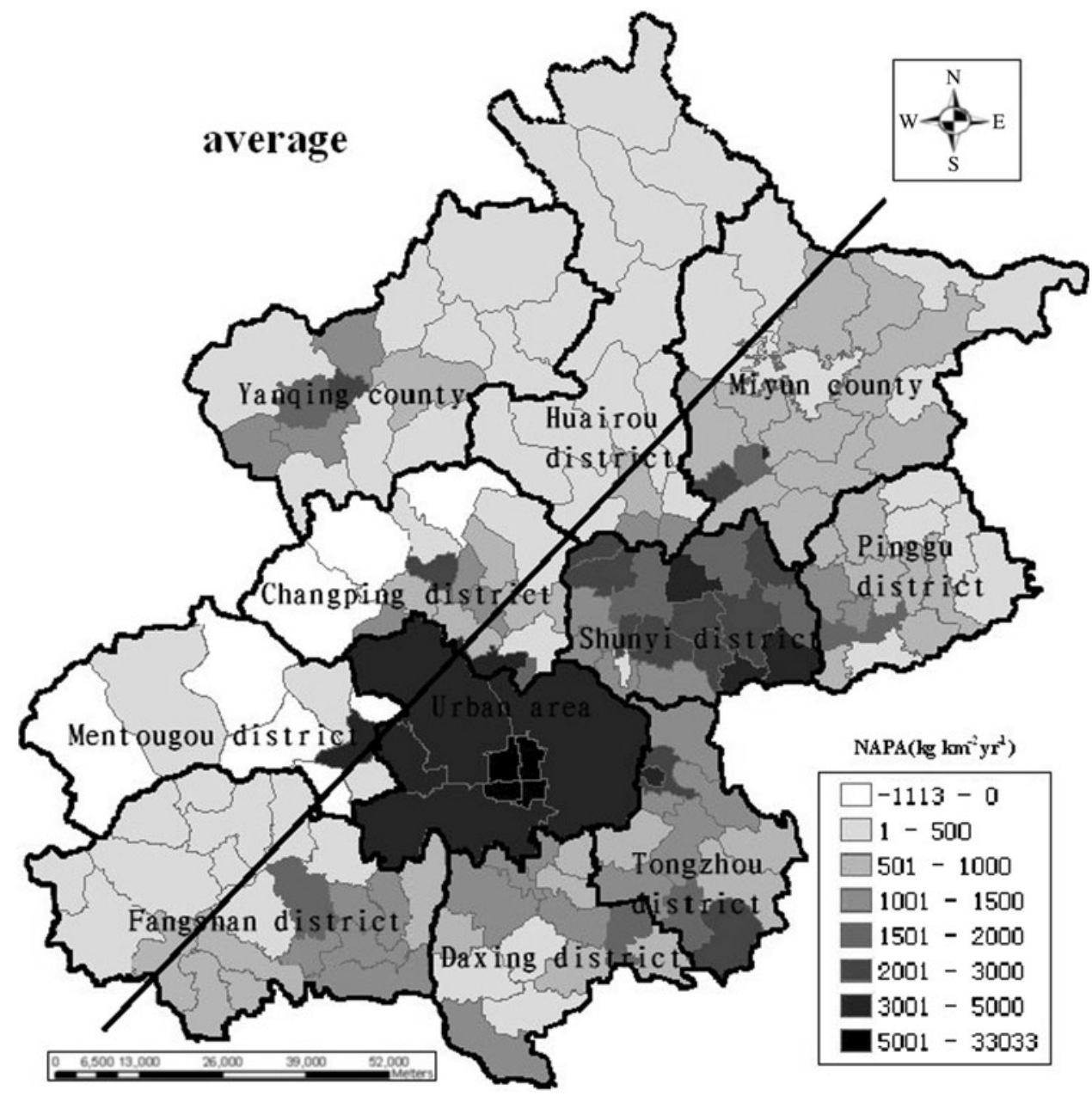

Figure 3. Average NAPA in subunits for 1991, 1997, 2003, and 2007. The slash is a diagonal line between northwest and southeast in Beijing. The black outline is the boundary of the subunits; the color of the units becomes darker with increasing of NAPA.
In Figure 3, if the whole of Beijing is divided into two parts with a clockwise $45^{\circ}$ oblique line, NAPA is lower in northwest Beijing than in southeast Beijing because NAPA has a strong relationship with regional development trends and progress. For example in the Yanqing unit, NAPA shows a decreasing trend from the center to the boundaries. This is because the county government is located in the most densely populated center, where the average population has been $1902 \mathrm{~km}^{-2}$ over the past 16 years. Likewise, in other research units the largest NAPA also occurs in the most densely populated centers where the district government, or important commercial base, is located. Thus, particular land types and activities strongly affected the magnitudes of NAPA.

\section{Temporal Variation of NAPA}

In 2003, the largest NAPA value appeared in all research units except the Urban unit and Yanqing unit (Figure 4; Table 5), because P fertilizer appli- cation showed an increasing trend between 1985 and 2005 and from 2005 on, it began to show a decreasing trend (Wu 2005). Among the 11 research units, only Urban unit NAPA showed an upward trend. In the Urban unit, the values of riverine net flux $\mathrm{P}$ are treated as constant in this paper, and the values of $\mathrm{P}$ in fertilizer use are very small, thus, the change in NAPA is mainly associated with the change in net $\mathrm{P}$ input/output in human food and animal feed and non-food P. Therefore, the upward trend of NAPA in the Urban unit indicates a growing population in this area.

In the other research units, the change of NAPA is mainly associated with regional characteristics, such as population density, fertilizer use, crop varieties, and so on. The Shunyi unit has the greatest change in NAPA over the last 16 years, followed by the Tongzhou unit. The average NAPA for the whole Beijing area over these years forms a parabola that opens downward, with the vertex occurring in 2003. 
Table 5. NAPA for Different Years

\begin{tabular}{|c|c|c|c|c|c|}
\hline & 1991 & 1997 & 2003 & 2007 & Average \\
\hline Urban & 5167 & 5,470 & 5,600 & 5,868 & 5,526 \\
\hline Yanqing & 172 & 370 & 672 & 687 & 475 \\
\hline Huairou & 173 & 182 & 168 & 154 & 169 \\
\hline Miyun & 184 & 489 & 620 & 619 & 478 \\
\hline Changping & 538 & 376 & 313 & 272 & 375 \\
\hline Shunyi & 1,155 & 2,530 & 2,817 & 2,209 & 2,178 \\
\hline Pinggu & 607 & 1,064 & 830 & 424 & 731 \\
\hline Mentougou & 122 & -282 & 283 & -260 & -34 \\
\hline Tongzhou & 876 & 779 & 2,005 & 1,850 & 1,378 \\
\hline Fangshan & 192 & 395 & 827 & 804 & 555 \\
\hline Daxing & 737 & 629 & 1,334 & 797 & 875 \\
\hline Beijing & 777 & 943 & 1,218 & 1,084 & 1,005 \\
\hline
\end{tabular}

Values in $\mathrm{kg} \mathrm{P} \mathrm{km}^{-2} \mathrm{y}^{-1}$. The data are on research unit-level NAPA for 4 years. The data below "Average" are the values averaged over the 4 years.

\section{Variation of NAPA Sources}

The sources of NAPA in Beijing were analyzed and Table 6 presents average values for each research unit. Table 6 shows that $\mathrm{P}$ input of fertilizer is the largest source of NAPA, accounting for $40.7 \%$ (455 kg P km${ }^{-2} \mathrm{y}^{-1}$ ) of the total P input, and the percentages were greater in the Tongzhou, Shunyi, and Fangshan units. The average non-food $\mathrm{P}$ is $403 \mathrm{~kg} \mathrm{P} \mathrm{km}^{-2} \mathrm{y}^{-1}$, accounting for $36.0 \%$ of the total P input, and specifically, it is $3128 \mathrm{~kg} \mathrm{P} \mathrm{km}^{-2}$ $\mathrm{y}^{-1}$ in the Urban unit and $156 \mathrm{~kg} \mathrm{P} \mathrm{km}^{-2} \mathrm{y}^{-1}$ in the other units.

Net $\mathrm{P}$ in human food and animal feed is proportional to the human population and animal numbers. In Beijing, dietary demands for P cannot be met by local crop and animal production, and the import of food and feed is necessary, so imports exceed exports. To be specific, the Urban unit has the greatest $\mathrm{P}$ input $\left(2811 \mathrm{~kg} \mathrm{P} \mathrm{km}^{-2} \mathrm{y}^{-1}\right)$ and the Tongzhou unit has the greatest P output $(246 \mathrm{~kg}$ P $\mathrm{km}^{-2} \mathrm{y}^{-1}$ ). Losses of $\mathrm{P}$ in riverine export averaged $114 \mathrm{~kg} \mathrm{P} \mathrm{km}^{-2} \mathrm{y}^{-1}$ in Beijing. Total $\mathrm{P}$ accumulations were established by aggregating the $\mathrm{P}$ input and output components.

Table 6 shows that $\mathrm{P}$ output is mainly from human food and animal feed as well as riverine $\mathrm{P}$ export in the entire Beijing area. $\mathrm{P}$ output in human food and animal feed indicates the food export. Riverine $\mathrm{P}$ export indicates that the rivers take away P from the study area, that is, the rivers are polluted, which is most significantly reflected in Changping district, where riverine $\mathrm{P}$ export accounts for $52.5 \%$ of total P import. Serious deterioration of surface water quality in Beijing is mainly because almost all of the current surface rivers serve as sewage channels and a large amount of industrial and household sewage flows into the rivers.

In Figure 5A, the percentage of $\mathrm{P}$ input in fertilizer use shows a downward trend in all research units except the Yanqing unit, which indicates that the nutrient accumulation caused by fertilizer use is reducing year by year, especially in the Huairou, Daxing and Changping units, with the fastest reductions of $22.3,19.8$, and $18.2 \%$, respectively. Land use in Beijing has changed little over the past 16 years (Gao and others 2001), so the sharp reduction in percentage of fertilizer use has no relationship with land use. Instead, it is a result of a rapid decrease in the amount of applied fertilizer per unit area.

In Figure $5 \mathrm{~B}$, the positive percentages of $\mathrm{P}$ for human food and animal feed indicate $\mathrm{P}$ input occurs, whereas the negative values indicate P output occurs. In the past 16 years the Urban, Pinggu, and Changping units maintained P input; Mentougou maintained P output; whereas $\mathrm{P}$ in the other units changed from a net output to an input. These changes are mainly caused by the growing population, which results in a rise in the absolute value of $\mathrm{P}$ in human food and animal feed.

Except for the Urban, Pinggu, Changping, and Mentougou units, the remaining research units need to import food and feed to meet daily consumption needs due to the destruction of the formerly self-sufficient agricultural lifestyle. Although the amount of non-food $\mathrm{P}$ in the whole Beijing area increased from $353 \mathrm{~kg} \mathrm{P} \mathrm{km}^{-2} \mathrm{y}^{-1}$ in 1991 to $462 \mathrm{~kg} \mathrm{P} \mathrm{km}{ }^{-2} \mathrm{y}^{-1}$ in 2007, its percentage to the 

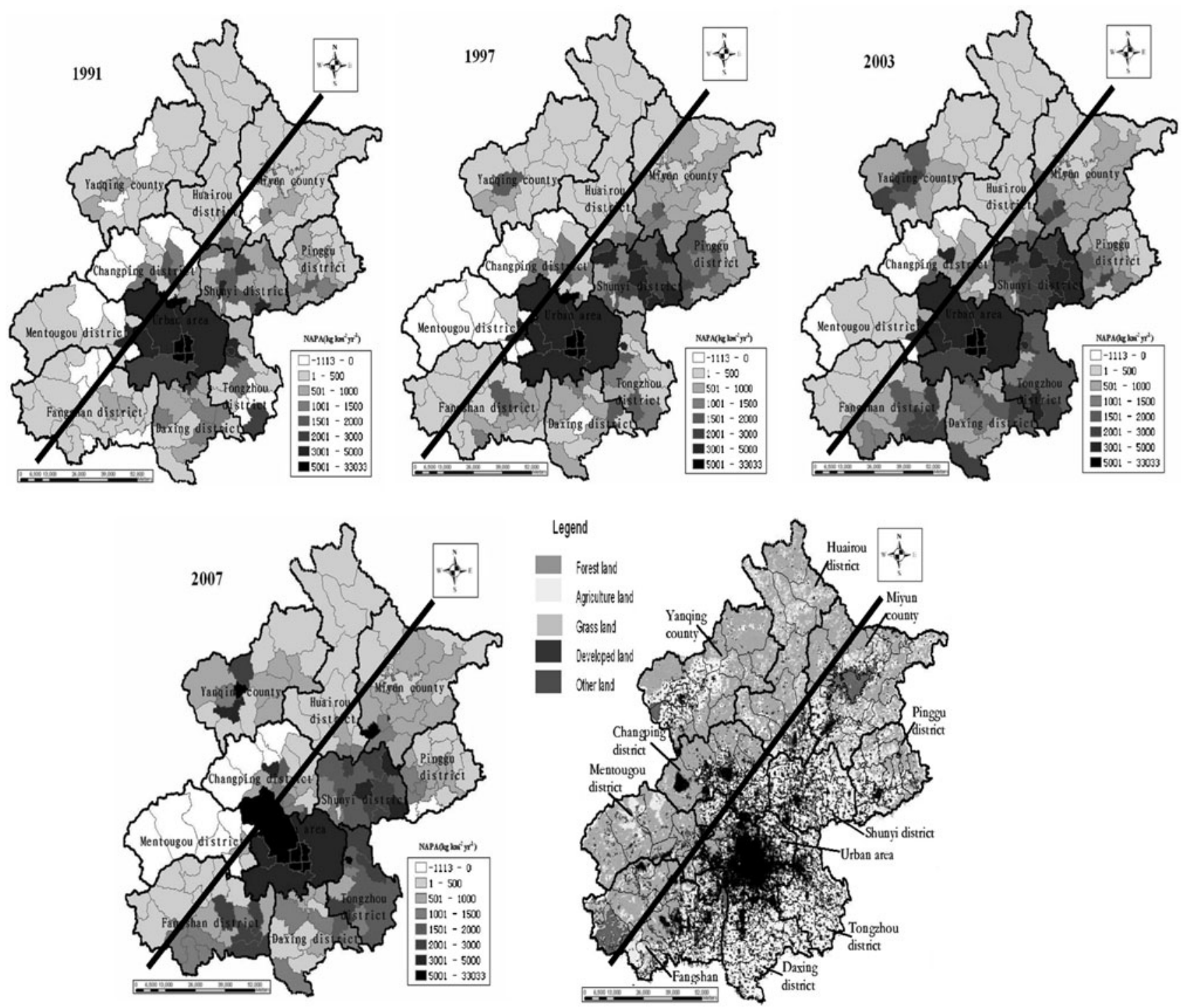

Figure 4. Temporal variation of NAPA in Beijing. The slash is a diagonal line between northwest and southeast in Beijing. The figure shows the NAPA based on the subunit-level data, and uses 1991, 1997, 2003, and 2007 as typical years to present the change of NAPA and land-use type in each research unit in 2007.

total input decreased, which is mainly caused by the rapid increase of $\mathrm{P}$ input. As for riverine net flux, we used the same absolute value for different years, so its percentage changed with NAPA only.

\section{Effects of Land Use on NAPA}

NAPA is affected by many factors, with the type of land use being one of the most important. Northwest Beijing is mainly covered by forest, where NAPA is relatively low, whereas southeast Beijing is mainly covered by agricultural and developed land, where NAPA is relatively high. Over the past 16 years, the average NAPA was $5433 \mathrm{~kg} \mathrm{P} \mathrm{km}^{-2} \mathrm{y}^{-1}$ in densely populated developed land, $503 \mathrm{~kg} \mathrm{P} \mathrm{km}^{-2} \mathrm{y}^{-1}$ in agricultural land and $84 \mathrm{~kg} \mathrm{P} \mathrm{km}^{-2} \mathrm{y}^{-1}$ in forest land. The Urban unit is a densely populated developed area, so it has the highest NAPA as shown in Figure 4. In agriculture-based southeast Beijing, NAPA is also higher because $\mathrm{P}$ in agricultural fertilizer is a major source of NAPA. As an example, in Yanqing in northwest Beijing, NAPA is highest in the developed land, followed by the agriculturebased land, and the lowest in the forest land.

In the past 16 years, the areas of agricultural land, forest land, grass land and other land shrank slightly, whereas the areas of developed land expanded. Generally, the reduction in agricultural 
Table 6. The Composition of NAPA

\begin{tabular}{|c|c|c|c|c|c|c|c|c|c|c|c|c|c|c|c|}
\hline & \multicolumn{9}{|l|}{ Input } & \multicolumn{5}{|c|}{ Output } & \multirow[t]{3}{*}{ NAPA } \\
\hline & \multicolumn{2}{|c|}{$\begin{array}{l}\text { Fertilizer } \\
\text { use }\end{array}$} & \multicolumn{2}{|c|}{$\begin{array}{l}P \text { in } \\
\text { human } \\
\text { food and } \\
\text { animal } \\
\text { feed }\end{array}$} & \multicolumn{2}{|l|}{$\begin{array}{l}\text { non- } \\
\text { food P }\end{array}$} & \multicolumn{2}{|c|}{ Riverine } & \multirow[t]{2}{*}{$\begin{array}{l}\text { Total } \\
\text { input }\end{array}$} & \multicolumn{2}{|c|}{$\begin{array}{l}P \text { in } \\
\text { human } \\
\text { food and } \\
\text { animal } \\
\text { feed }\end{array}$} & \multicolumn{2}{|c|}{ Riverine } & \multirow[t]{2}{*}{$\begin{array}{l}\text { Total } \\
\text { output }\end{array}$} & \\
\hline & $\mathrm{P}$ & $(\%)$ & $P$ & $(\%)$ & $\mathrm{P}$ & $(\%)$ & $\mathbf{P}$ & $(\%)$ & & $P$ & $(\%)$ & $P$ & $(\%)$ & & \\
\hline Urban & 1 & & 2,811 & 47.3 & 3,128 & 52.7 & & & 5,940 & & & -414 & 100.0 & -414 & 5,526 \\
\hline Yanqing & 332 & 70.0 & 49 & 10.3 & 76 & 16.0 & 18 & 3.7 & 475 & & & & & 0 & 475 \\
\hline Huairou & 117 & 64.6 & & & 63 & 34.7 & 1 & 0.7 & 181 & -11 & 100.0 & & & -11 & 169 \\
\hline Miyun & 220 & 46.0 & 154 & 32.2 & 103 & 21.5 & 1 & 0.3 & 478 & & & & & 0 & 478 \\
\hline Changping & 165 & 20.9 & 455 & 57.7 & 169 & 21.4 & & & 789 & & & -414 & 100.0 & -414 & 375 \\
\hline Shunyi & 1,869 & 84.7 & & & 335 & 15.2 & 1 & 0.1 & 2,205 & -27 & 100.0 & & & -27 & 2,178 \\
\hline Pinggu & 498 & 66.0 & 78 & 10.3 & 178 & 23.6 & & & 754 & & & -23 & 100.0 & -23 & 731 \\
\hline Mentougou & 27 & 17.8 & & & 109 & 70.8 & 18 & 11.4 & 154 & -188 & 100.0 & & & -188 & -34 \\
\hline Tongzhou & 1,809 & 88.0 & & & 246 & 12.0 & & & 2,056 & -264 & 38.9 & -414 & 61.1 & -678 & 1,378 \\
\hline Fangshan & 470 & 70.3 & & & 192 & 28.7 & 7 & 1.0 & 669 & -115 & 100.0 & & & -115 & 554 \\
\hline Daxing & 875 & 67.9 & 89 & 6.9 & 325 & 25.2 & & & 1,289 & & & -414 & 100.0 & -414 & 875 \\
\hline Beijing & 455 & 40.7 & 261 & 23.3 & 403 & 36.0 & & & 1,119 & & & -114 & 100.0 & -114 & 1,005 \\
\hline
\end{tabular}

The data in this table are the average values for the four typical years. We calculated P input and output, respectively, and obtained the value of NAPA using the calculated input plus output. The other figures are the absolute values with units of $\mathrm{kg} \mathrm{P} \mathrm{km}^{-2} \mathrm{y}^{-1}$.

land, forest land and grass land will lead to a decrease of NAPA; and the expansion of developed land indicates a population growth, thereby inevitably causing an increase of NAPA.

\section{Discussion}

\section{Analysis of Main Predictors of NAPA}

As discussed previously, the change in NAPA is mainly associated with changes in P fertilizer use, net $\mathrm{P}$ input/output in human food and animal feed and non-food P. P fertilizer use is further associated with total fertilizer application, and net $\mathrm{P}$ input/ output in human food and animal feed and nonfood $\mathrm{P}$ is further associated with population. Thus, we select these two parameters, population density and amount of applied fertilizer, as predictors of NAPA. A stepwise linear regression analysis was conducted for NAPA (Table 7).

By analysis of variance, we examined whether there is a linear relationship between $y$ (NAPA) and $x_{1}$ (population density) and $x_{2}$ (amount of applied fertilizer) at the level $P=0.001$. Population density was the best predictor for singly forecasting NAPA, where $R^{2}=0.962$ (see Figure 6). Therefore, population density is a main factor controlling NAPA differences among various human ecosystems. When two predictors, population density and amount of applied fertilizer, were used to forecast
NAPA, $R^{2}=0.968$. So, a better result can be obtained if these two predictors are both used to forecast NAPA.

\section{Comparison of Beijing with Other Parts of the World}

To further understand the extent of pollution in Beijing, we compared the accumulated P in Beijing with that in some developed countries (see Table 8).

The value of accumulated $\mathrm{P}$ in America and Australia ranges from $407 \mathrm{~kg} \mathrm{P} \mathrm{km}^{-2} \mathrm{y}^{-1}$ to $660 \mathrm{~kg}$ $\mathrm{P} \mathrm{km}^{-2} \mathrm{y}^{-1}$, whereas the average NAPA in Beijing reached $1005 \mathrm{~kg} \mathrm{P} \mathrm{km}^{-2} \mathrm{y}^{-1}$, about two times that of the former. In the study of Jaworski and others (1992) and Lester and others (2000), agricultural land had higher levels than other land types, so NAPA was relatively higher due to agricultural application of P fertilizers. In the study of Russell and others (2008), agricultural land had the same percentage as in this study. However, the NAPA we obtained was twice his. That's because the population in our study area is greater than in his study area, that is, the development land area in our study is larger than in his study. There was no significant difference in the percentage of riverine $\mathrm{P}$ export between our study and other studies. However, as NAPA in our study was relatively higher, the absolute value of riverine $\mathrm{P}$ export was higher in our study than in other studies. 

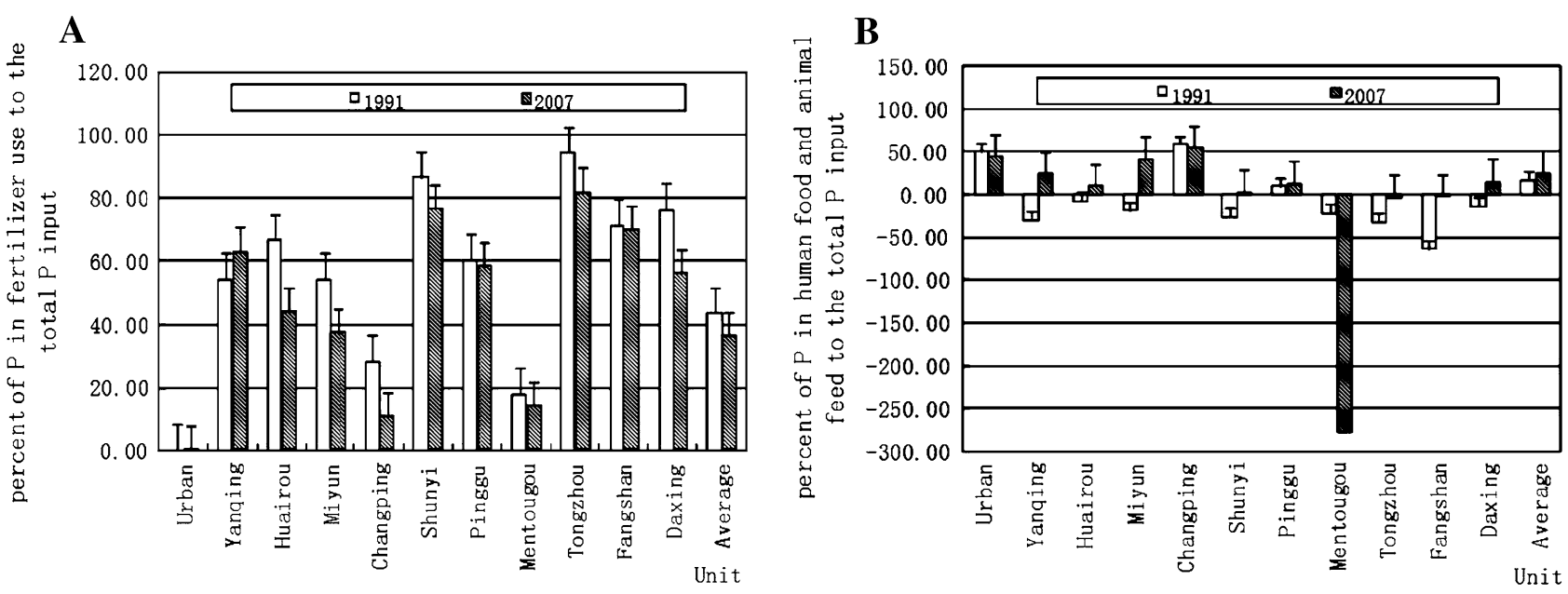

C
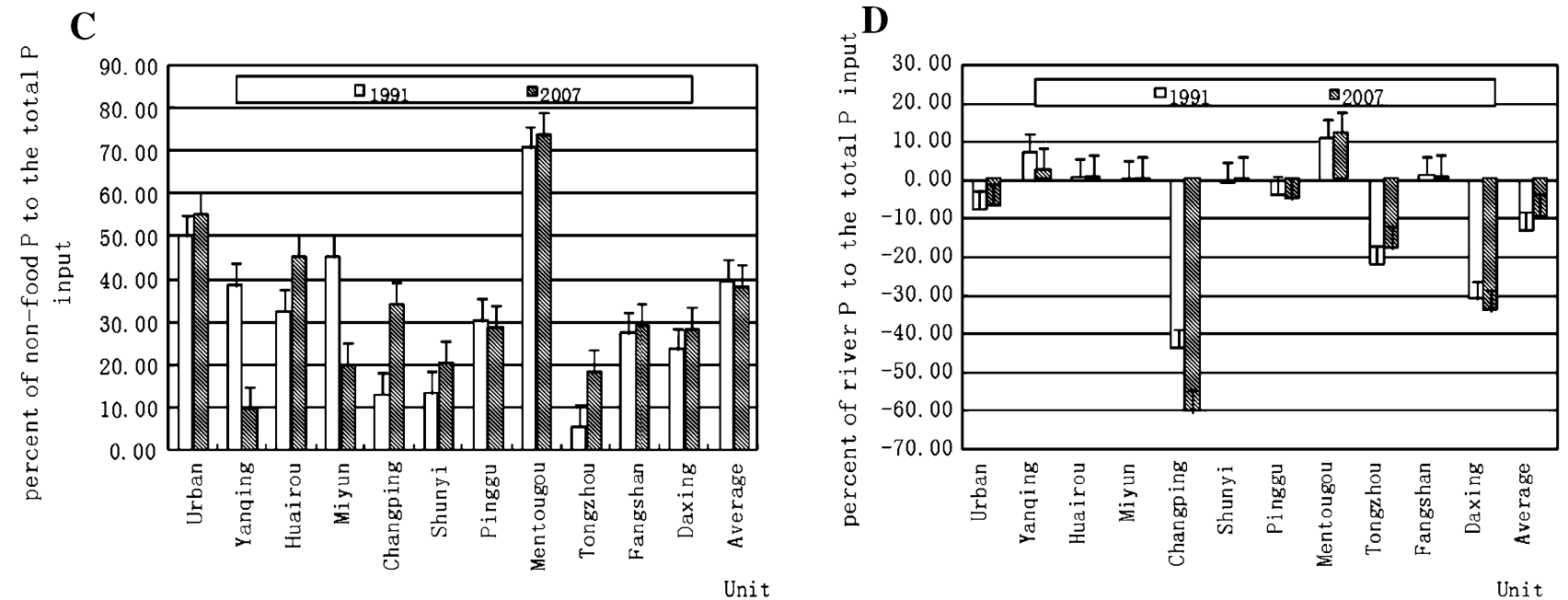

Figure 5. The percentage of each component in NAPA between 1991 and 2007 were analyzed. This figure shows A percentage of $\mathrm{P}$ in fertilizer use of the total $\mathrm{P}$ input, B percentage of $\mathrm{P}$ in human food and animal feed of the total $\mathrm{P}$ input, $\mathbf{C}$ percentage of non-food $\mathrm{P}$ of the total $\mathrm{P}$ input, and $\mathbf{D}$ percentage of river $\mathrm{P}$ of the total $\mathrm{P}$ input. In the abscissa are the names of the 11 research units, and in the ordinate are the percentages.

Table 7. Main Predictors of NAPA

\begin{tabular}{lccc}
\hline & Coefficients & $R^{2}$ & $F$ \\
\hline Constant & 502.781 & 0.962 & 16762.281 \\
$x_{1}$ (population density) & 1.123 & & 0.968 \\
Constant & 292.622 & & 9957.999 \\
$x_{1}$ (population density) & 1.130 & & 0.00 \\
$x_{2}$ (the amount of fertilizer use) & 0.102 & &
\end{tabular}

The data were analyzed with SPSS17.02. Below the "Model" are the constants and influencing factors which constitute the model; $R$ is correlation coefficient; " $F$ " is F-test for the regression coefficients.

In association with the studies of other countries, the largest source of NAPA is fertilizer application and non-food P. The large amount of NAPA accumulation in Beijing is mainly caused by a relatively denser population and more fertilizer application.
With the reduction in agricultural fertilizer use, $\mathrm{P}$ accumulation caused by population growth will become increasingly serious. According to the relevant statistics, the population in Beijing increased 9.67 million in the past decade and had reached 


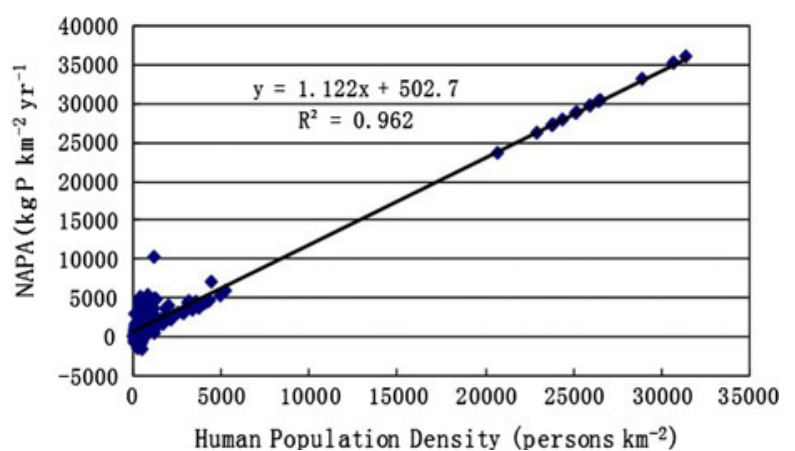

Figure 6. NAPA relationship with human population density.

30.74 million by February, 2009. The rising population results in a deterioration in the living environment and a series of environmental problems. Only when the problem of uneven development among cities is eliminated and transportation is improved, can the population in Beijing be controlled. However, improvement takes time.

\section{Fate of NAPA}

From the above analysis we can see that Beijing accumulates a huge amount of P every year. But, where has it gone? Part of it has accumulated in plants and animals, which is an important mode of $\mathrm{P}$ accumulation. Animals and plants cannot survive without $\mathrm{P}$, because $\mathrm{P}$ is an important component of animal nucleic acid of genetic material and is involved in plant photosynthesis and respiration. Part of it has accumulated in the soil. A lot of fertilizer is applied into the soil, but plants absorb no more than 50\% (Wang and others 2010). P not absorbed by plants accumulates in the soil, resulting in many environmental problems such as soil compaction. The other part of $\mathrm{P}$ in human excretion flows through sewers into the river. The $\mathrm{P}$ accumulation in the groundwater and the river leads to eutrophication of water, which results in loss of ecological functions for water, thereby bringing about serious environmental problems such as the death of aquatic animals and plants.

To 2007, $90 \%$ of household sewage in Beijing was treated by a sewage treatment plant (Gu 2008). After the treatment, the sewage was filtered out $90 \%$ of $\mathrm{P}$ that was left in the sludge of the sewage treatment plant and would eventually be landfilled (Zhang and others 2009). Based on the population of Beijing in 2007, it could be calculated that $680 \mathrm{~kg} \mathrm{P} \mathrm{km} \mathrm{k}^{-2} \mathrm{y}^{-1}$ of $\mathrm{P}$ was landfilled. In recent years, research on re-use of sewage sludge is being conducted (for example, used as agricultural fertilizer and the production of biogas, and so on), but

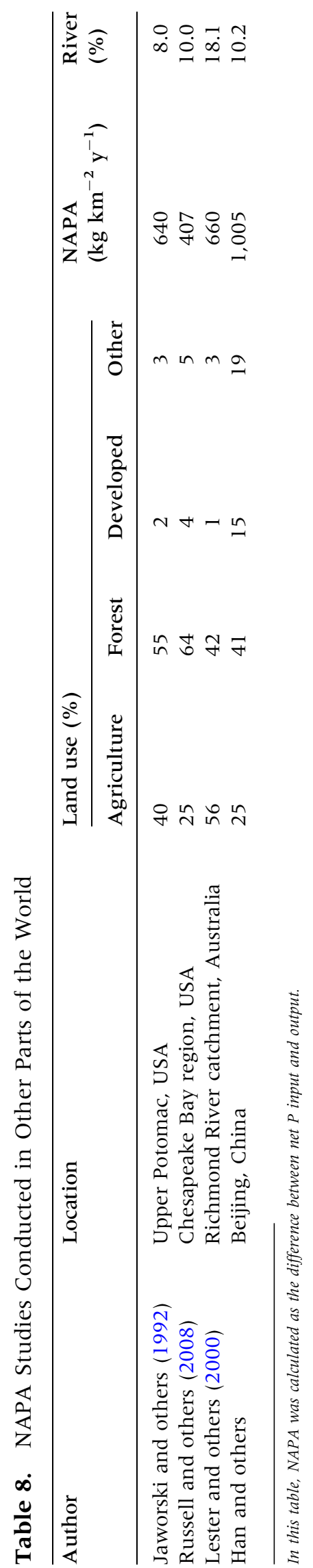


currently has not been applied on a large scale (Xiong and Zhang 2007).

\section{To Control the Sources of P Pollution}

First of all, reasonable urban planning is needed, which may play an obvious role in regulating and controlling $\mathrm{P}$ pollution from the perspective of population. Reasonable urban planning may include measures such as reasonable population distribution and a public transportation system, the key point being to change the existing intensive work and life style, which, however, requires a long time. Secondly, scientific fertilizer application, especially the use of organic fertilizer should be emphasized. The amount, manner and time of organic fertilizer application should be based on soil properties, crop growing conditions, and properties of the crop in absorbing the nutrition (Liu and others 2010). Thirdly, the disposal of agricultural wastes such as livestock manure and crop straw should be regulated. P pollution caused by directly abandoned agricultural wastes cannot be ignored as they are rich in organic matter and nutrients. Biological waste management and centralized livestock management should be adopted to prevent $\mathrm{P}$ loss in the agricultural surface water. In addition, crop residue and straw play an important practical role in controlling soil erosion, inhibiting nutrient loss, and preventing P pollution.

\section{To Control P Diffusion}

Currently, an effective method for controlling P diffusion is by means of ecological engineering. Generally, P diffusion is controlled by inhibiting runoff and increasing infiltration. Many countries are developing a buffer zone to control P pollution, for example, the vegetative filter zone in the United States and the buffer region in Britain. After years of experimental studies ( $\mathrm{Fu}$ and others 2006), Chengqing Yin has found that the multiple-ponds method may prevent up to $94 \%$ of P pollution. P pollution can also be effectively controlled by means of a combination of engineering measures, and biological measures with water and soil conservation through building sand-sinking pools, percolation ponds, water catchments and water treatment facilities.

\section{Conclusion}

This study took a step forward to calculate the accumulation of $\mathrm{P}$ in detail on a regional scale, and analyzed its temporal variations and geographic differences. The overall average NAPA values for the years of 1991, 1997, 2003, and 2007 were 777 943,1218 , and $1084 \mathrm{~kg} \mathrm{P} \mathrm{km}^{-2} \mathrm{y}^{-1}$, respectively. The Urban unit had the largest NAPA $(5526 \mathrm{~kg} \mathrm{P}$ $\mathrm{km}^{-2} \mathrm{y}^{-1}$ ), whereas Mentougou $\mathrm{P}$ was negative, outputting $34 \mathrm{~kg} \mathrm{P} \mathrm{km} \mathrm{km}^{-2} \mathrm{y}^{-1}$, being about two times that reported in developed countries. On a geographical basis, the accumulation was heaviest in east and south Beijing, and the NAPA distribution was basically similar to the distribution of population and agricultural land. P input of fertilizer was the largest source of NAPA, accounting for $40.7 \%$ (455 kg P km${ }^{-2} \mathrm{y}^{-1}$ ) of the total $\mathrm{P}$ input, followed by non-food $\mathrm{P}$ and $\mathrm{P}$ in human food and animal feed. Human population density was the best single predictor of NAPA. In summary, this study provides a new understanding of sources of $\mathrm{P}$ in Beijing, and serves as a foundation for further exploration of anthropogenic effects on $\mathrm{P}$ accumulation.

\section{ACKNOWLEDGMENTS}

Funding for this work was supported by the National Natural Science Foundation of China (Grant Nos. 40971271 \& 41071323), the CAS FEA International Partnership Program for Creative Research Teams of "Ecosystem Processes and Services" (Grant No. KZCX2-YW-T13), and the State Key Laboratory of Urban and Regional Ecology (Grant No. SKLURE2008-1-05).

\section{REFERENCES}

Beijing water authority. 2006. Beijing water resources bulletin. Beijing water authority.

Beijing water authority. 2007. Beijing water resources bulletin. Beijing water authority.

Beijing water authority. 2008. Beijing water resources bulletin. Beijing water authority.

Denman KL. 2007. In: Solomon S et al., Eds. Climate change 2007: the physical science basis. Contribution of working group 1 to the fourth assessment. Report of the Intergovernmental Panel on Climate Change. Cambridge: Cambridge University Press. pp 499-587.

Fu Q, Yin CQ, Shan BQ. 2006. Phosphorus sorption capacities in a headstream landscape - The pond chain structure. J Environ Sci China 18:1004-11.

Gao XZ, Ma WQ, Du S, Zhang FS, Mao DR. 2001. Current status and problems of fertilization in China. Chin J Soil Sci 32(6):258-61.

Grove JM, Burch WR Jr. 1997. A social ecology approach and applications or urban ecosystem and landscape analyses: a case study of Baltimore, Maryland. Urban Ecosyst 1:259-75.

Gu H. 2008. Beijing sewage treatment rate of $90 \%$. Special Struct 25:112.

Jaworski NA, Goffman PM, Keller AA. 1992. A watershed nitrogen and phosphorous balance: the upper Potomac river basin. Estuaries 15:83-95. 
Jordan TE, Weller DE. 1996. Human contributions to terrestrial nitrogen flux. Bioscience 46:655-64.

Kitchell JF, Ed. 1992. Food web management: a case study of Lake Mendota. New York: Springer-Verlag.

Lester J, Mc K, Bradley DE. 2000. Nitrogen and phosphorus budgets for the sub-tropical Richmond River catchment, Australia. Biogeochemistry 50:207-39.

Li J, Ed. 2007. Animal nutrition and feed. Chongqing, China: Chongqing University Press.

Liang CH, Ed. 1999. Common fertilizers and their application techniques. Shengyang, China: Shengyang Press. pp 94-96.

Liu SM, Zhu BD, Zhang J. 2010. Environmental change in Jiaozhou Bay recorded by nutrient components in sediments. Mar Pollut Bull 60:1591-9.

Lowrance RR, Leonard RA, Asmussen LE. 1985. Nutrient budgets for agricultural watersheds in the southeastern coastal plain. Ecology 66:287-96.

Mcdonnell MJ, Pickett STA. 1990. Ecosystem structure and function along urban rural gradients-an unexploited opportunity for ecology. Ecology 71:1232-7.

McIsaac GF, David MB, Gertner GZ. 2001. Nitrate flux in the Mississippi River. Nature 414:166-7.

Pickett STA, Burch WR Jr, Dalton SE, Foresman TW, Grove JM, Rowntree R. 1997. A conceptual framework for the study of human ecosystems in urban areas. Urban Ecosyst 1:185-99.

Pickett STA, Cadenasso ML, Grove JM, Nilon CH, Pouyat RV, Zipperer WC, Costanza R. 2001. Urban ecological systems: linking terrestrial ecological, physical, and socioeconomic components of metropolitan areas. Annu Rev Ecol Syst 32:127-57.

Russell MJ, Weller DE, Jordan TE. 2008. Net anthropogenic phosphorus inputs: spatial and temporal variability in the Chesapeake Bay region. Biogeochemistry 88:285-304.
Shang XJ. 2009. Study on plant species selection and wastewater purification efficiency in constructed wetlands in Beijing. China: Chin Acad For. p 21.

Sukopp H. 1990. Urban ecology and its application in Europe. In: Sukopp H, Hejny S, Kowarik I, Eds. Urban ecology: plants and plant communities in urban environments. The Hague (The Netherlands): SPB Academic. p 1-22.

Sun YJ, Wang QX, Lu ZH. 2005. Effects of urbanization on landscape pattern of Beijing. Chin J Appl Ecol 16:1366-9.

Van Horn HHH. 1998. Factors affecting manure quantity, quality, and use. Proceedings of the Mid-South Ruminant Nutrition Conference, Dallas-Ft. Worth, May 7-8, 1998. Texas Animal Nutrition Council, pp 78-93.

Wang YG. 2003. The brief introduction of the progress of food composition table in China. Acta Nutr Sin 25:126-9.

Wang XB, Dai K, Wang Y. 2010. Nutrient management adaptation for dryland maize yields and water use efficiency to long-term rainfall variability in China. Agricult Water Manag 97:1344-50.

Wu SX. 2005. The spatial and temporal change of nitrogen and phosphorus produced by livestock and poultry $\&$ their effects on agricultural non-point pollution in China. The Chinese Academy of Agricultural Science, China, pp 12-16.

Xiong S, Zhang SD. 2007. Evaluation of land application of sewage sludge in Beijing. J Hebei Inst Archit Civil Eng 25:36-9.

Yan P, Ma KM. 2007. Expanding process of urban areas at different scales: a case study in Beijing region. Acta Ecol Sin 27:2137-44.

Zhang H, Zhao S, Zhou J, Gan YP. 2009. Status of sewage plant sludge in the Beijing. Civil Eng Technol 7:53-4. 